\title{
Correction to: Polarized nature of the COVID-19 pandemic in Japan: associations with population age structure and behaviours
}

\author{
Junko Okumura ${ }^{1,2}$
}

\section{Correction to: Trop Med Health 49, 38 (2021) \\ https://doi.org/10.1186/s41182-021-00324-0}

Following publication of the original article [1], the authors identified an error in Fig. 1. The wrong part is the location of the red-line to indicate the $30 \%$ line. The correct figure is given below.

The original article [1] has been corrected.

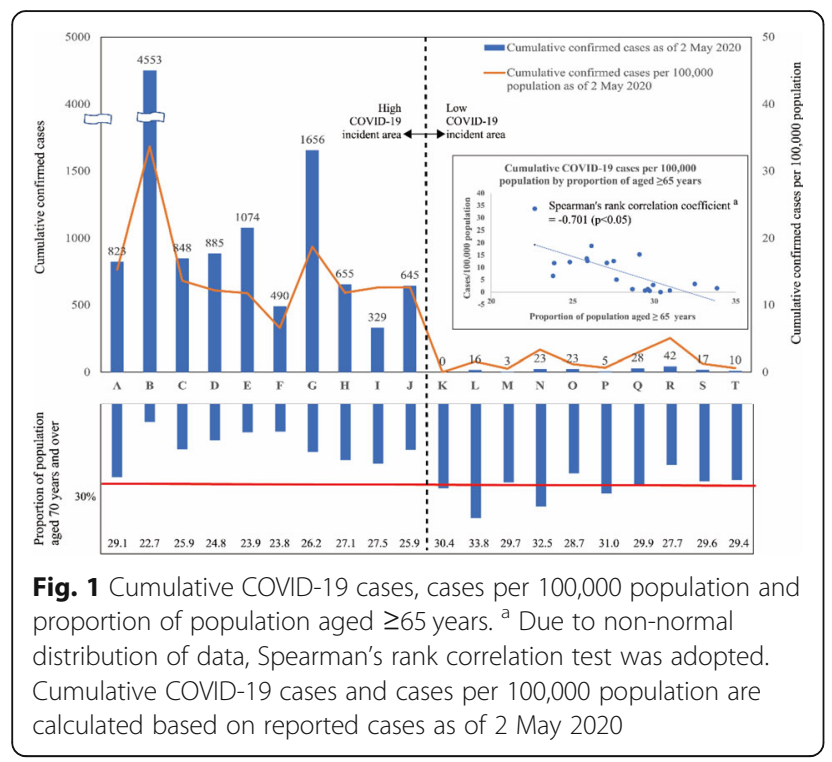

The original article can be found online at https://doi.org/10.1186/s41182021-00324-0.

Correspondence: jokumura@nagasaki-u.ac.jp

'Institute of Tropical Medicine, Nagasaki, Japan

${ }^{2}$ School of Tropical Medicine and Global Health, Nagasaki University, 1-12-4 Sakamoto, Nagasaki, Nagasaki 852-8523, Japan
Published online: 29 July 2021

\section{Reference}

1. Okumura J. Polarized nature of the COVID-19 pandemic in Japan: associations with population age structure and behaviours. Trop Med Health. 2021;49:38. https://doi.org/10.1186/s41182-021-00324-0.

\section{BMC}

(0) The Author(s). 2021 Open Access This article is licensed under a Creative Commons Attribution 4.0 International License, which permits use, sharing, adaptation, distribution and reproduction in any medium or format, as long as you give appropriate credit to the original author(s) and the source, provide a link to the Creative Commons licence, and indicate if changes were made. The images or other third party material in this article are included in the article's Creative Commons licence, unless indicated otherwise in a credit line to the material. If material is not included in the article's Creative Commons licence and your intended use is not permitted by statutory regulation or exceeds the permitted use, you will need to obtain permission directly from the copyright holder. To view a copy of this licence, visit http://creativecommons.org/licenses/by/4.0/. 